\title{
Potential of Artocarpus heterophyllus Seed Powder in the Adsorption of Chromium(VI) from Aqueous Solution
}

\author{
Cranmer Lubanga, Emmanuel Ntambi, Christopher Adaku \\ Chemistry Department, Faculty of Science, Mbarara University of Science and Technology, Mbarara, Uganda \\ Email:emmantambi@must.ac.ug
}

How to cite this paper: Lubanga, C. Ntambi, E. and Adaku, C. (2017) Potential of Artocarpus heterophyllus Seed Powder in the Adsorption of Chromium(VI) from Aqueous Solution. Journal of Water Resource and Protection, 9, 614-628. https://doi.org/10.4236/jwarp.2017.96041

Received: February 13, 2017

Accepted: May 19, 2017

Published: May 22, 2017

Copyright () 2017 by authors and Scientific Research Publishing Inc. This work is licensed under the Creative Commons Attribution International License (CC BY 4.0).

http://creativecommons.org/licenses/by/4.0/

\begin{abstract}
The potential of Artocarpus heterophyllus (Jackfruit) seed powder in adsorption of chromium(VI) from aqueous solution was studied using batch technique. The performance of the adsorption process was evaluated against contact time, $\mathrm{pH}$, adsorbent dose, temperature and initial chromium(VI) ion concentration. The influence of the presence of interfering anionic species including chlorides, nitrates and sulphates on the adsorption process was also evaluated. The adsorption of chromium(VI) by Jackfruit seed powder reached equilibrium after 60 minutes. Higher chromium(VI) adsorption was observed at lower $\mathrm{pH}$ values with maximum removal (96.05\%) occurring at $\mathrm{pH} 2$. A great deal of adsorption (92.53\%) was observed at the adsorbent dosage level of $1.0 \mathrm{~g} / 100 \mathrm{ml}$ solution. There was an improvement in the adsorption process when the temperature was increased from $25^{\circ} \mathrm{C}(95.35 \%)$ to $60^{\circ} \mathrm{C}(99.56 \%)$ followed by a decrease to $98.76 \%$ at $70^{\circ} \mathrm{C}$. Adsorption decreased with increasing initial chromium(VI) ion concentration. The adsorption followed both Freundlich and Langmuir adsorption models with correlation coefficients of 0.998 and 0.994 respectively, and $Q_{m}$ of $0.57 \mathrm{mg} / \mathrm{g}$. The presence of nitrate and chloride ions significantly lowered the adsorption, with all the $\mathrm{p}$ values $<0.05$ at $95 \%$ significant level. Meanwhile, the presence of sulphate ions enhanced chromium(VI) adsorption as most of the $\mathrm{p}$ values were $>0.05$. From the obtained $Q_{m}$, Jackfruit Seed Powder is a good adsorbent for the aqueous solutions of $\mathrm{Cr}(\mathrm{VI})$. The adsorption process is slowed by the presence of the interfering anionic species.
\end{abstract}

\section{Keywords}

Chromium(VI), Artocarpus heterophyllus, Adsorption, Interfering Ions

\section{Introduction}

Chromium(VI) is one of the major heavy metals of great concern in wastewater 
management. Most of the chromium contamination in Uganda arises from industrial activities which include leather tanning, cement mining, electroplating, photography, dye manufacturing, and fertilizer industries. Majority of these industries are small scale and cannot afford the conventional methods of treating wastewater containing chromium. These industries therefore, channel untreated or partially treated effluents into the neighbouring water bodies, especially Lake Victoriaor deposit precipitated chromium into landfills from where it leaches into the underground water [1]. The level of chromium contamination in Jinja wetlands close to the tannery industry in Uganda has reached as high as 271 ppm compared to the recommended limits in soils of 40 - $50 \mathrm{ppm}$ [2] [3]. Therefore, there is a need to search for cheaper and environmentally friendly alternative methods to alleviate the chromium pollution challenge.

Some studies show that heavy metals can be removed from aqueous solution using plant materials such as papaya seeds [4], Molinga oliefera [5], wheat bran [6]. Such plant materials extract metals by adsorption process which is regarded as the most efficient method due to its low costs, availability, design simplicity, easy operation, biodegradability and ability to treat solutes in a more concentrated form.

In this study, the effectiveness of Artocarpus heterophyllus (jackfruit) seed powder in removing the chromium(VI) from aqueous solution by adsorption was investigated. The Artocarpus heterophyllus believed to originate from the rain forests of the Western Ghats of India is the largest tree-born fruit in the world. It is widely distributed in Uganda, both cultivated and wild, and a popular food item. The juicy pulp is commonly eaten as dissert but the seeds are often regarded as a waste and therefore, discarded. Since the seeds can be readily obtained from the consumers in large quantities, it might provide material for the remediation of chromium contamination from the contaminated water system as well.

\section{Materials and Methods}

\subsection{Adsorbent}

Fresh jackfruit seeds were collected from Bugema village, Luwero district, Ugandain February, 2013 and the seed coat removed. The seeds were dried completely under the sun for 30 days, pulverised and sieved using a sieve of particle size $710 \mu \mathrm{m}$.

\subsection{Reagents}

A stock solution containing $100 \mathrm{mg} \cdot \mathrm{l}^{-1}$ of $\mathrm{Cr}(\mathrm{VI})$ was prepared by dissolving $0.2828 \mathrm{~g}$ of $\mathrm{AR}$ grade potassium dichromate, $\mathrm{K}_{2} \mathrm{Cr}_{2} \mathrm{O}_{7}$ (Merck) in distilled water to make $1000 \mathrm{~mL}$ of solution. The stock solution was appropriately diluted to give $\mathrm{Cr}(\mathrm{IV})$ standard solutions of the required concentrations. The $\mathrm{pH}$ of the standard solutions was adjusted with either $0.1 \mathrm{M}$ sulphuric acid or $0.1 \mathrm{M}$ sodium hydroxide solution. 


\subsection{Batch Adsorption Procedure}

Batch adsorption studies were conducted at different conditions to assess the potential of jackfruit seed powder in the adsorption of $\mathrm{Cr}(\mathrm{VI})$ from aqueous solution. Experimental procedures followed were as outlined in [7] in triplicates and the average of the results reported. $\mathrm{Cr}(\mathrm{VI})$ concentration in the solutions was determined by the standard colorimetric method using 1,5-diphenylcarbazide in an acid medium, which gave a violet complex with acidified $\mathrm{Cr}(\mathrm{VI})$ [8]. Metal concentration in the solution was analysed with a digital colorimeter at wavelength $(\lambda)$ of $545 \mathrm{~nm}$ which gave the absorbance of $\mathrm{Cr}(\mathrm{VI})$ ions [9]. Percentage adsorption $\left(A_{e q}\right)$ and adsorption capacity $\left(Q_{e}\right)$ at equilibrium were determined using the equations below;

$$
\begin{gathered}
A_{e q}=\frac{C_{o}-C_{e}}{C_{o}} \times 100 \\
Q_{e}=\frac{V\left(C_{o}-C_{e}\right)}{W}
\end{gathered}
$$

where; $V$ is the initial solution volume (L), $C_{o}$ and $C_{e}$ are theinitial and equilibrium $\mathrm{Cr}(\mathrm{VI})$ concentration of the solution $\left(\mathrm{mg} \cdot \mathrm{l}^{-1}\right)$, and $W$ is the amount of JSP (g).

The effect of initial $\mathrm{pH}$, contact time, temperature, adsorbent dosage level and initial chromium(VI) ion concentration were determined as per the procedures described by [6] as below.

\subsection{Effect of Initial pH}

While maintaining all other factors constant, the initial $\mathrm{pH}$ of the standard $\mathrm{Cr}(\mathrm{VI})$ solution was varied from $1,2,3,4,5,6,7,8,9$ and 10 using $0.1 \mathrm{M} \mathrm{H}_{2} \mathrm{SO}_{4}$ or $0.1 \mathrm{M} \mathrm{NaOH}$ solution. Jackfruit seed powder $(2.0 \mathrm{~g})$ was added to $250 \mathrm{ml} \mathrm{Py}$ rex glass beaker containing $5 \mathrm{mg} \cdot \mathrm{l}^{-1} \mathrm{Cr}(\mathrm{VI})$ solution $(100 \mathrm{ml})$. The mixture was agitated using a glass rod every after 10 minutes. After 1 hour, $10 \mathrm{ml}$ of the solution was obtained, to which was added $0.2 \mathrm{ml}$ of $0.1 \mathrm{M} \mathrm{H}_{2} \mathrm{SO}_{4}$ followed by $1 \mathrm{ml}$ of 1,5-diphenyl carbazide. The solution was left to stand for 5 to 10 minutes and residual concentration of Chromium(VI) determined.

\subsection{Effect of Contact Time}

Jackfruit seed powder $(2.0 \mathrm{~g})$ was added to $100 \mathrm{ml}$ of $5 \mathrm{mg} \cdot \mathrm{l}^{-1}$ chromium(VI) solution at $\mathrm{pH} 2$ for $1,3,5,10,20,30,40,50,60,90$ and 120 minutes at $25^{\circ} \mathrm{C}$. The mixture was filtered and the amount of residual chromium(VI) in solution determined.

\subsection{Effect of Temperature}

Jackfruit seed powder (2.0 g) was added to $100 \mathrm{ml}$ of $5 \mathrm{mg} \cdot \mathrm{l}^{-1}$ chromium(VI) solution at $\mathrm{pH} 2$ while maintaining the temperature at $25,30,40,50,60$ and $70^{\circ} \mathrm{C}$ using a water bath for 1 hour. 


\subsection{Effect of Adsorbent Dosage Level}

Different masses of jackfruit seed powder $(0.2,0.5,0.8,1.0,1.5,2.0$ and $3.0 \mathrm{~g})$

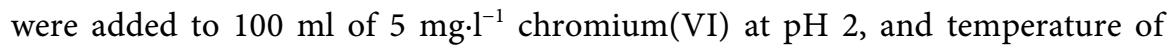
$25^{\circ} \mathrm{C}$ and the mixture stirred after every 10 minutes for 1 hour.

\subsection{Effect of Initial Chromium(VI) Ion Concentration}

Jackfruit seed powder $(2.0 \mathrm{~g})$ was added to $100 \mathrm{ml}$ of 5.0, 7.5, 10.0, 12.5, 15.0, 17.5 and $20.0 \mathrm{mg} \cdot \mathrm{l}^{-1}$ of chromium(VI) at the $\mathrm{pH} 2$ for 1 hour while maintaining the temperature at $25^{\circ} \mathrm{C}$.

\subsection{Effect of Interfering Ions}

Effect of interfering ions was determined as per the procedure listed in [10] \& [11].

A solution of chromium(VI) $\left(100 \mathrm{ml}, 5.0 \mathrm{mg} \cdot \mathrm{l}^{-1}\right)$ was added different sodium chloride, potassium nitrate or sodium sulphate of concentration of $0,5,10$ and $20 \mathrm{~g} / \mathrm{l}$ at $\mathrm{pH}$ 2. To the resulting solutions, $2.0 \mathrm{~g}$ of jackfruit seed powder was added. While maintaining the temperature at $25^{\circ} \mathrm{C}$, the mixture was stirred after every 10 minutes for 1 hour. The procedure was repeated for $7.5 \mathrm{mg} \cdot \mathrm{l}^{-1}$ chro$\operatorname{mium}(\mathrm{VI})$.

\section{Results and Discussion}

\subsection{Effect of Initial $\mathrm{pH}$}

$\mathrm{Cr}(\mathrm{VI})$ removal by JSP was found to be highly dependent on the initial $\mathrm{pH}$ of the solution as illustrated by Figure 1. The optimal $\mathrm{pH}$ for the removal of $5 \mathrm{mg} \cdot \mathrm{l}^{-1}$ $\mathrm{Cr}(\mathrm{VI})$ by the jackfruit seeds was 2.0 (96.05\% removal). At low $\mathrm{pH}$, the surface of the JSP (active sites) became positively charged owing to the protonation of its functional groups (amines, carbxyl, and hydroxyl) and hence increasing the attraction for the $\mathrm{HCrO}_{4}^{-}$, predominant at $\mathrm{pH} 2$ and below [12]. As the $\mathrm{pH}$ increases, sites become less protonated and the electrostatic force of attraction between JSP and chromium(VI) anionic species decreases leading to reduction in

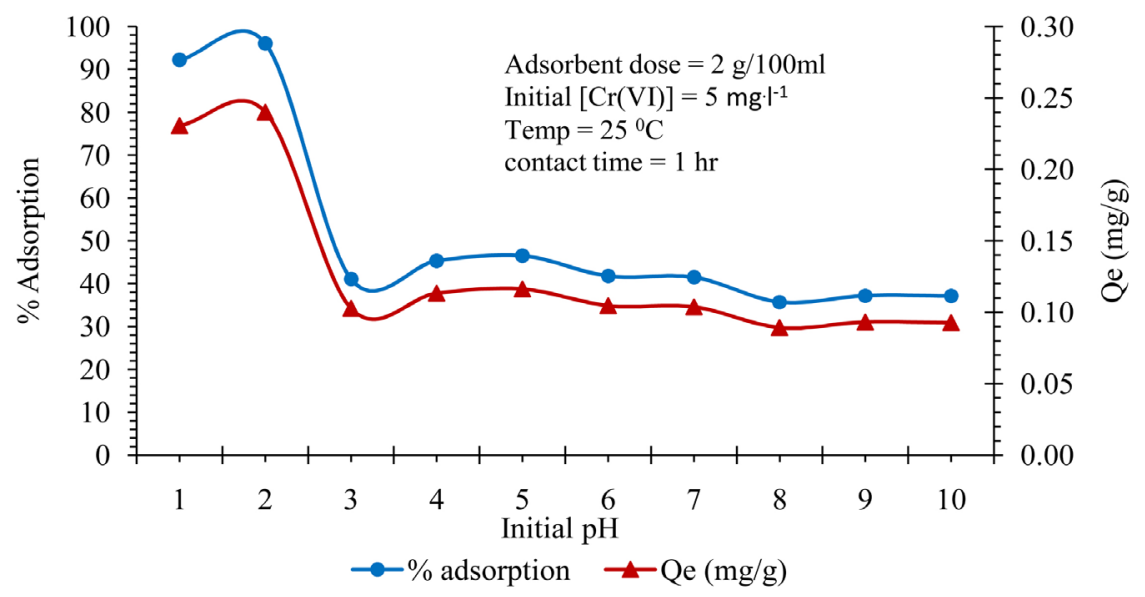

Figure 1. Effect of initial $\mathrm{pH}$ on $\mathrm{Cr}(\mathrm{VI})$ adsorption percentage and percentage. 
perecentage adsorption. The $\mathrm{pH}$ best suitable for the adsorption of $\mathrm{Cr}(\mathrm{VI})$ species by plant seeds is 2 [4] [5] [13].

There was a slight change in the $\mathrm{pH}$ of the solution after the whole adsorption process as illustrated by Figure 2. This may be attributed to ion exchange between jackfruit seed powder surface and matrix interface. It may also be due to the adsorption of chromate ion by ion exchange mechanism as depicted in the equations below [14].

$$
\begin{gathered}
\mathrm{R}-\mathrm{OH}+\mathrm{HCr}_{2} \mathrm{O}_{7}^{-} \rightarrow \mathrm{R}-\mathrm{HCr}_{2} \mathrm{O}_{7}+\mathrm{OH}^{-} \\
\mathrm{R}-\mathrm{COOH}+\mathrm{HCr}_{2} \mathrm{O}_{7}^{-} \rightarrow \mathrm{R}-\mathrm{CO}-\mathrm{HCr}_{2} \mathrm{O}_{7}+\mathrm{OH}^{-}
\end{gathered}
$$

\subsection{Effect of Contact Time}

The general increase in adsorption as per Figure 3 was due to the time allowed

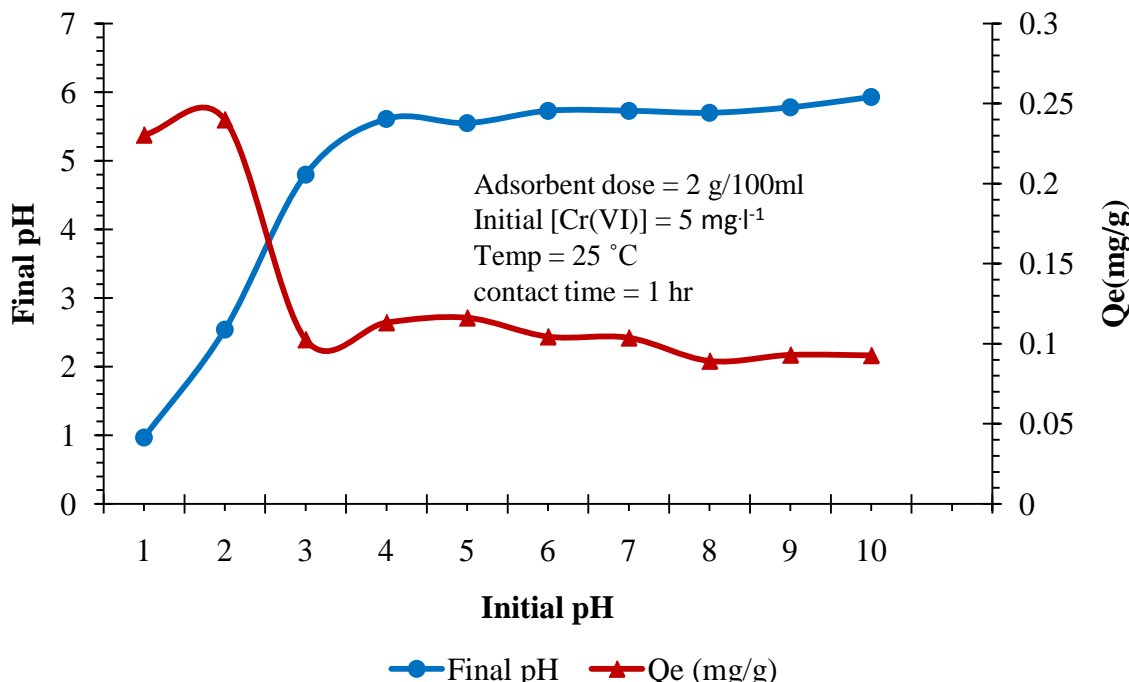

Figure 2. Final $\mathrm{pH}$ and adsorption capacity varying with initial $\mathrm{pH}$.

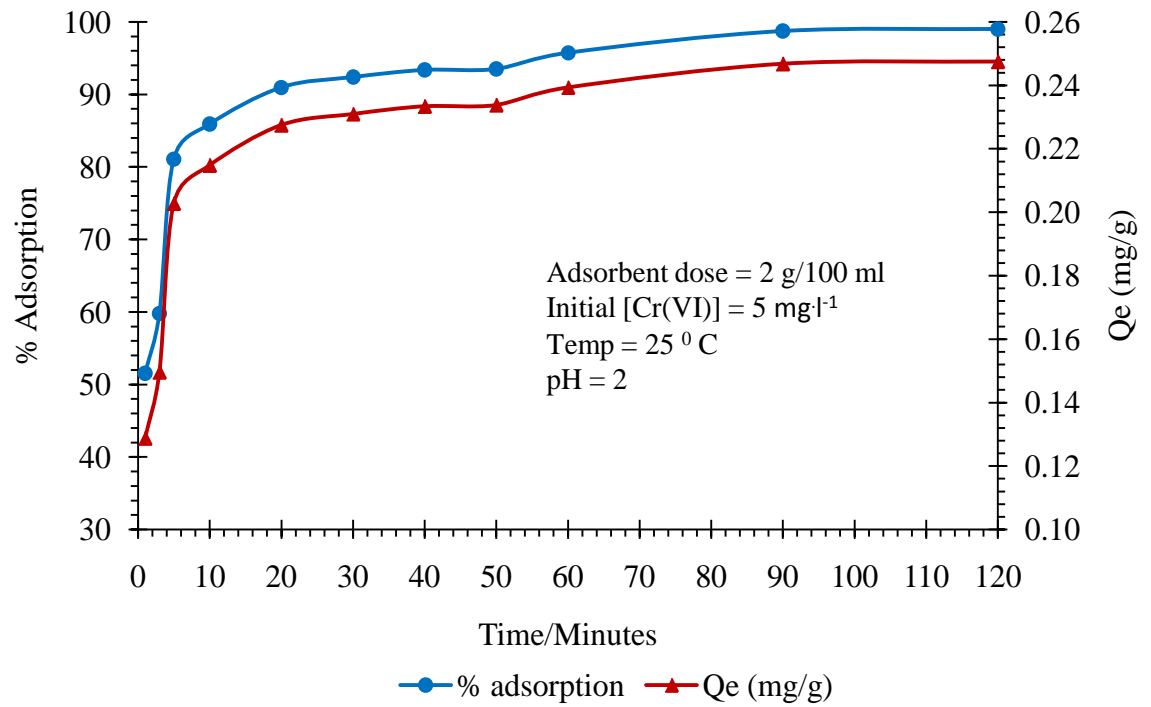

Figure 3. Effect of contact time on adsorption capacity and percentage of $\mathrm{Cr}(\mathrm{VI})$ by JSP. 
for the chromium(VI) ions to interact with the JSP active sites. The initial rapid rate of adsorption leading up to $85.91 \%$ adsorption after 10 minutes may be due to the availability of the free active sites on JSP for the $\mathrm{Cr}(\mathrm{VI})$ ions. The next gradual adsorption rate to $98.73 \%$ at 90 minutes was either due to the electrostatic hindrance caused by the already adsorbed chromium(VI) anionic species and the incoming ions, or reduced probability of the chromium(VI) in finding a free adsorption site, since most active sites are already occupied [15]. Similar trend of results were obtained as in [5].

\subsection{Effects of Temperature}

The general increase in adsorption in Figure 4 with temperature is attributed to the provision of the thermal energy, required to overcome the energy barrier for active sites and chromium(VI) bond formation [15]. The effect of temperature on the adsorption process is twofold; increasing the temperature increases the diffusion rate of the chromium(VI) ions in solution; and secondary, changing the temperature will modify the equilibrium capacity of the adsorbent for a particular adsorbate [13]. However, adsorption beyond $60^{\circ} \mathrm{C}$ decreased to $98.76 \%$, owing to desorption of adsorbed species at high temperatures. As the temperature is increased, the thermal energy is also increased and hence increasing mobility of the chromium(VI) ion in solution. Thus desorption rate outweighed the rate of adsorption at high thermal energy (beyond $60^{\circ} \mathrm{C}$ ) [15].

\subsection{Effect of Adsorbent Dosage}

Figure 5 shows a general increase of adsorption percentage with adsorbent dose, which was due to the increased contact surface. It was more probable for $\mathrm{HCrO}_{4}^{-}$and $\mathrm{CrO}_{4}^{2-}$ ions to adsorbed onto the jackfruit seed powder active sites leading to increased adsorption percentage [6].

On the contrary adsorption capacity diminished with increasing adsorbent dose because adsorption capacity is inversely proportional to the adsorbent

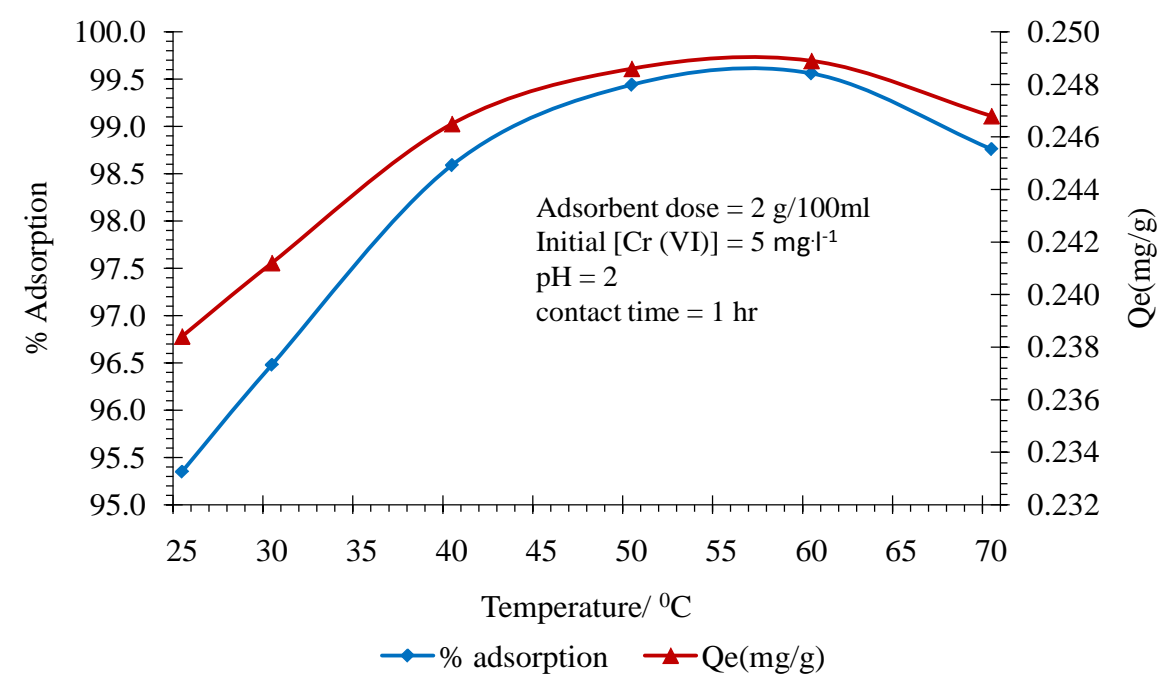

Figure 4. Effect of temperature on adsorption percentage and capacity of $\mathrm{Cr}(\mathrm{VI})$. 


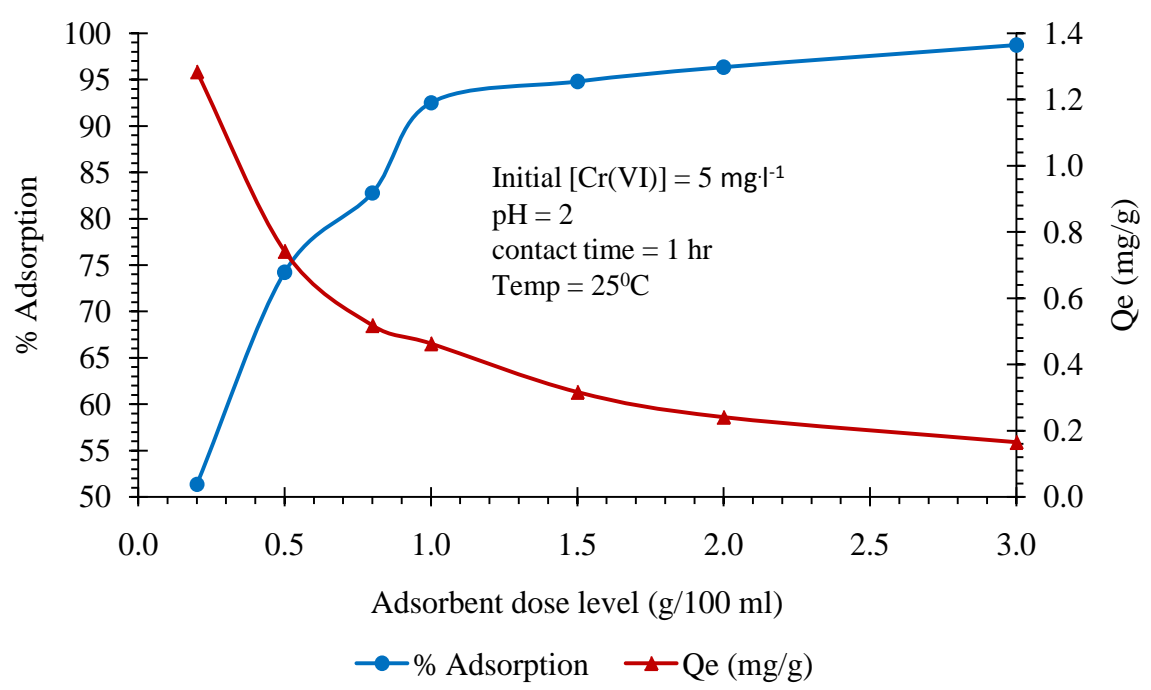

Figure 5. Effect of adsorbent dosage level on adsorption percentage and capacity of Cr(VI).

dosage level.

\subsection{Effect of Initial Cr(VI) Ion Concentration}

Percentage adsorption decreased with initial ion concentration as illustrated by Figure 6. At low $\mathrm{Cr}(\mathrm{VI})$ concentrations, there are many jackfruit seed powder active sites for the few ions and subsequently fractional adsorption is independent of the initial concentration. However, at higher concentrations, the available sites for adsorption become fewer and hence the percentage removal of $\mathrm{Cr}(\mathrm{VI})$ ion which depends upon the initial concentration decreases [6]. On increasing the initial concentration, the adsorption capacity increased towards the saturation point owing to the increasing availability of $\mathrm{Cr}(\mathrm{VI})$ at the interface, thus enhancing the degree of adsorption [14]. Increasing the concentration of chromium(VI) ions in solution increased the availability of chromium(VI) ions at the interface, thus enhancing adsorption.

\subsection{Evaluation of the Thermodynamic Parameters}

The adsorption thermodynamic parameters were determined from the relations as described in [11] [13] [15].

The standard change in the Gibbs free energy was calculated from

$$
\Delta G^{o}=-R T \ln K_{c}
$$

where $R$ is gas constant $\left(8.314 \mathrm{~kJ} \cdot \mathrm{mol}^{-1}\right)$ and $T$ is temperature in kelvin $(\mathrm{K}), K_{c}$ is the equilibrium constant obtained by the equation below

$$
K_{c}=\frac{C_{a d}}{C_{o}}
$$

$C_{a d}$ is the concentration of $\mathrm{Cr}(\mathrm{VI})$ adsorbed onto the JSP at a given temperature, $C_{o}$ is initial $\mathrm{Cr}(\mathrm{VI})$ concentration.

Finally, the standard enthalpy change $\Delta H^{\circ}$ of $+61789.648 \mathrm{~J} \cdot \mathrm{mol}^{-1}$ and entropy 
changes $\Delta S^{\circ}$ of $+232.38 \mathrm{JK}^{-1} \cdot \mathrm{mol}^{-1}$ were obtained using the slope and intercept of Figure 7 from the linear Vant Hoff plot as illustrated by Equation (5) below.

$$
\ln K_{c}=\frac{\Delta S^{o}}{R}-\frac{\Delta H^{o}}{R}\left[\frac{1}{T}\right]
$$

The positive value of $\Delta H^{0}$ indicated that the adsorption process between jackfruit seed powder and chromium(VI) was endothermic [11], implying monolayer accompanying chemisorption. Therefore, it requires heat to overcome the energy barrier for adsorption to take place [15]. The positive value of $\Delta S^{0}$ reflected an increase in affinity of chromium(VI) towards jackfruit seed powder as well as an increase in the degree of disorder and randomness of the reaction mixture with temperature.

The negative values of $\Delta G$ indicated the feasibility and spontaneity of the adsorption process. Furthermore, the amount of $\Delta G^{\circ}(>41.858 \mathrm{~kJ}$ or $10 \mathrm{kcal})$ suggests

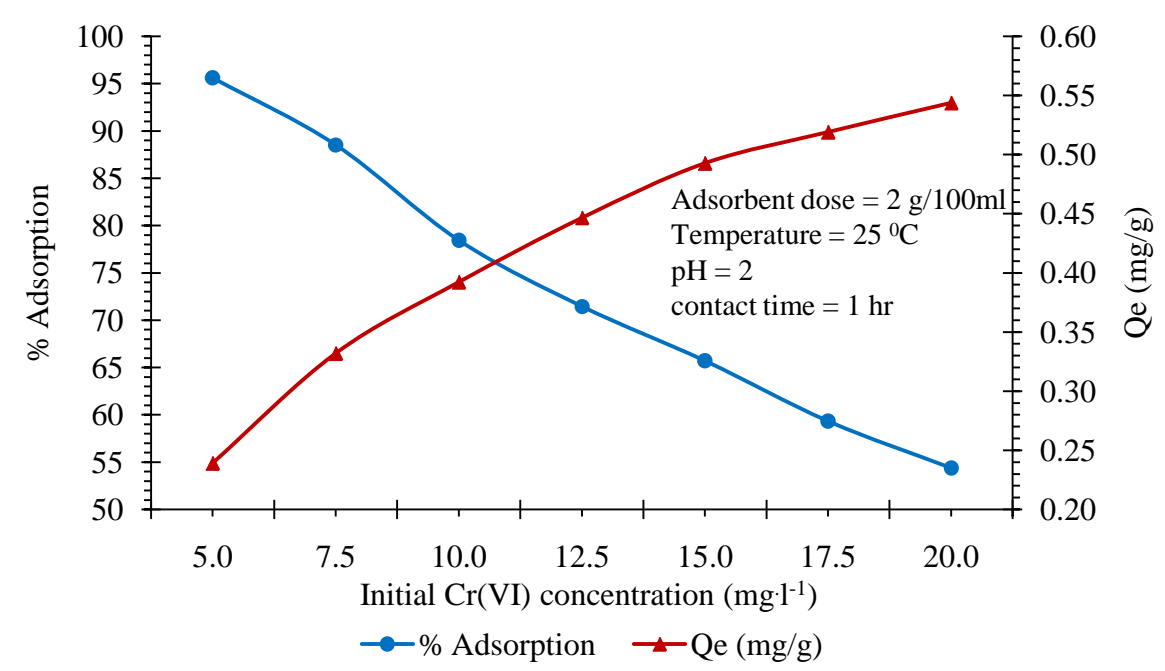

Figure 6. Adsorption percentage and capacity varying with initial ion concentration.

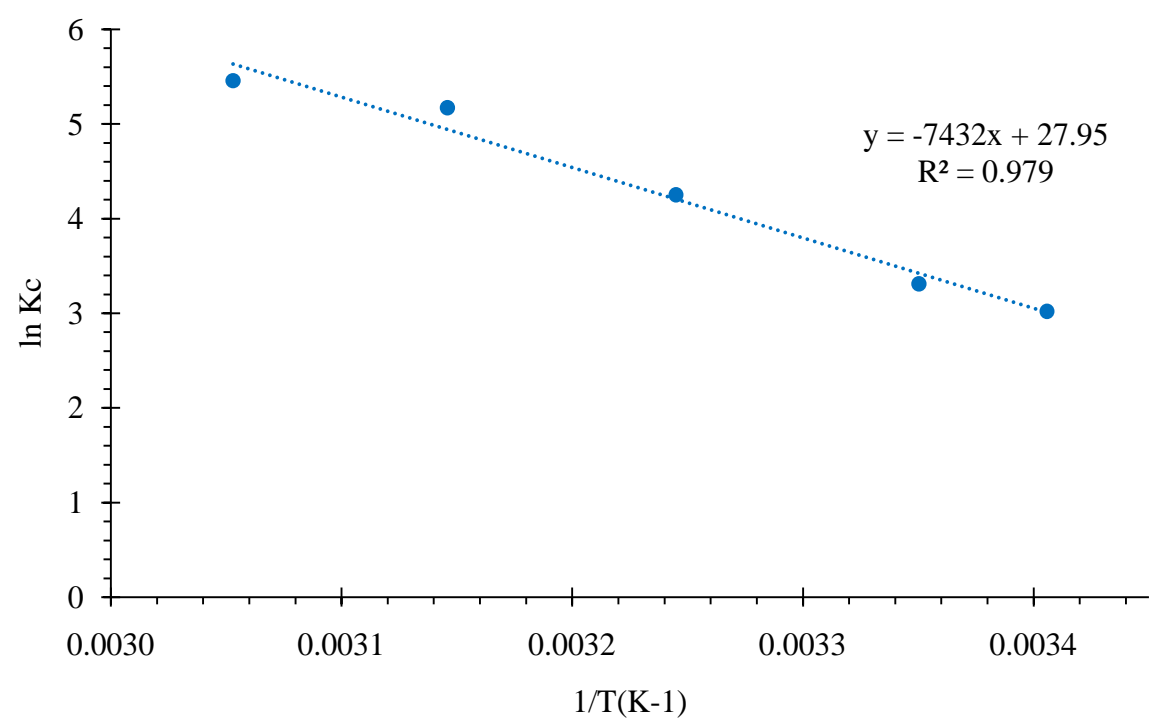

Figure 7. A graph of $\ln K_{c}$ against $1 / T$ for the evaluation of $\Delta H^{p}$ and $\Delta S^{\circ}$. 
that adsorption is chemical. The increasing magnitude of $\Delta G^{\circ}$ with temperature as shown in Table 1 shows that adsorption is more favourable with temperature increase [13].

\subsection{Effects of Interfering Ions}

Presence of a salt in the solution introduced interfering anionic species that competed with chromium(VI) for the same jackfruit seed powder adsorption sites. Interference significantly occurred in presence of the nitrate and chloride ions as per Figure 8 and Figure 9. Reduced adsorption was greatly manifested at higher salt concentrations. This is because increasing the salt concentration increased the number of interfering nitrate or chloride ions in the solution, enhancing competition for the jackfruit seed powder adsorption sites.

Table 1. Thermodynamic parameters for chromium(VI) adsorption by the JSP.

\begin{tabular}{ccccccc}
\hline Temp. (K) & $1 / T\left(\mathrm{~K}^{-1}\right)$ & $K_{c}$ & $\ln K_{c}$ & $\begin{array}{c}\Delta G^{\mathrm{o}} \\
\left(\mathrm{J} \cdot \mathrm{mol}^{-1}\right)\end{array}$ & $\begin{array}{c}\Delta H^{\circ} \\
\left(\mathrm{J} \cdot \mathrm{mol}^{-1}\right)\end{array}$ & $\begin{array}{c}\Delta S^{o} \\
\left(\mathrm{JK}^{-1} \cdot \mathrm{mol}^{-1}\right)\end{array}$ \\
\hline 298 & 0.0034 & 20.4961 & 3.02 & -7459.592 & & \\
303 & 0.0033 & 27.3768 & 3.31 & -8621.492 & & \\
313 & 0.0032 & 69.9220 & 4.25 & -10945.292 & +61789.648 & +232.38 \\
323 & 0.0031 & 176.3050 & 5.17 & -13269.092 & & \\
333 & 0.0030 & 235.9668 & 5.46 & -15592.892 & & \\
\hline
\end{tabular}

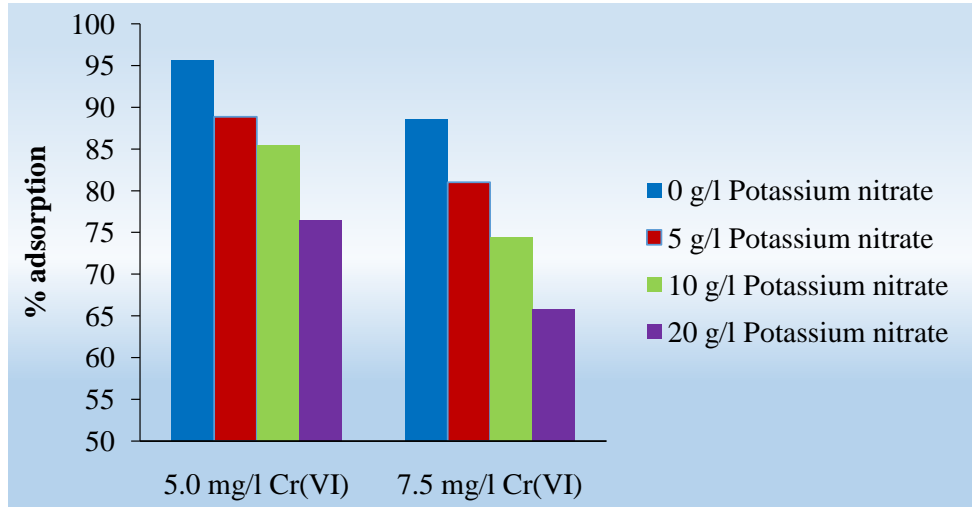

Figure 8. The effect of $\mathrm{NO}_{3}^{-}$ion on $\mathrm{Cr}(\mathrm{VI})$ adsorption by JSP.

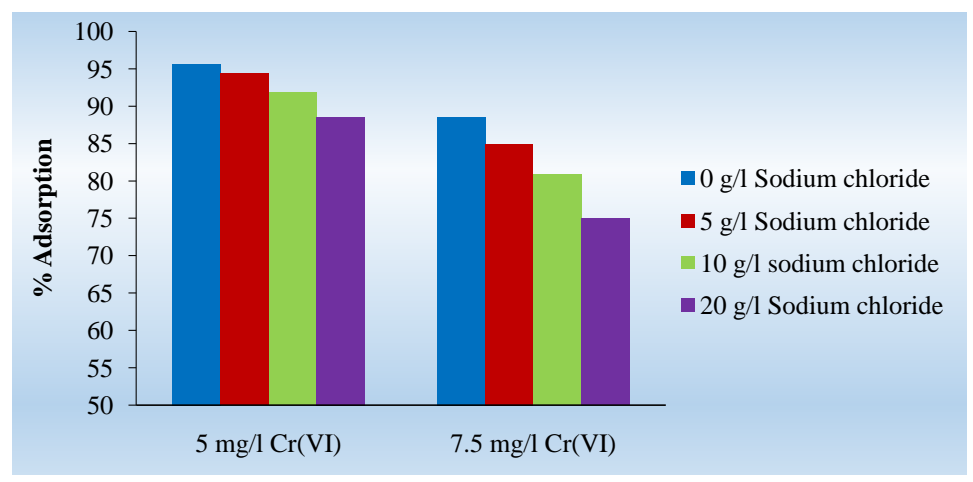

Figure 9. The effect of $\mathrm{Cl}^{-}$ion on $\mathrm{Cr}(\mathrm{VI})$ adsorption by JSP. 
Interference by the chloride or nitrate ions was because of their relative small size as compared to $\mathrm{HCrO}_{4}^{-}$in addition to possession of the same charge (single negative), and hence targeting the same positively charged JSP active sites. Similar trend of results were obtained as per [14].

On the contrary, increasing sodium sulphate concentration and hence sulphate $\left(\mathrm{SO}_{4}^{2-}\right)$ ions in solution favoured adsorption of more chromium(VI) as shown by Figure 10. It could be attributed to the combined effect of $\mathrm{SO}_{4}^{2-}$ from sulphuric acid and sodium sulphate.

In this case, the jackfruit seed powder may have acted as a reducing agent owing to the presence of electron-donor groups under acidic conditions. In turn, $\mathrm{Cr}(\mathrm{VI})$ probably received electron which then reduced it to $\mathrm{Cr}(\mathrm{III})$ [16]. The $\mathrm{Cr}$ (III) could have then reacted with the sulphate ions forming a complex [17].

From Table 2, $\mathrm{Cr}(\mathrm{VI})$ adsorption in presence of nitrate ions $(\mathrm{p}<0.05)$ indicated $\mathrm{Cr}(\mathrm{VI})$ adsorption interference by nitrate ions. Similar results in presence of chloride ion were also observed. The $\mathrm{p}$ values further indicated that increasing interfering ions or $\mathrm{Cr}(\mathrm{VI})$ ions in solution, further hindered adsorption. Most of the results obtained in presence of sulphate ions had $\mathrm{p}>0.05$, meaning that presence of sulphate ions in solution instead favours $\mathrm{Cr}(\mathrm{VI})$ adsorption process. Therefore presence of some ionic species in waste water may interfere with the $\mathrm{Cr}(\mathrm{VI})$ adsorption process by either enhancing or retarding it.

\subsection{Adsorption Isotherms}

Two adsorption isotherm models were selected to fit the data, namely the Langmuir and Freundlich models [18]. The Langmuir assuming a monolayer adsorption is,

$$
Q_{e}=\frac{Q_{m} K_{a} C_{e}}{1+K_{a} C_{e}}
$$

where $Q_{m}$ is the maximum adsorption capacity, while $K_{a}$ is a coefficient related to the affinity between the adsorbent and metal ions also related to the energy of adsorption, used to determine a dimensionless constant separation factor or

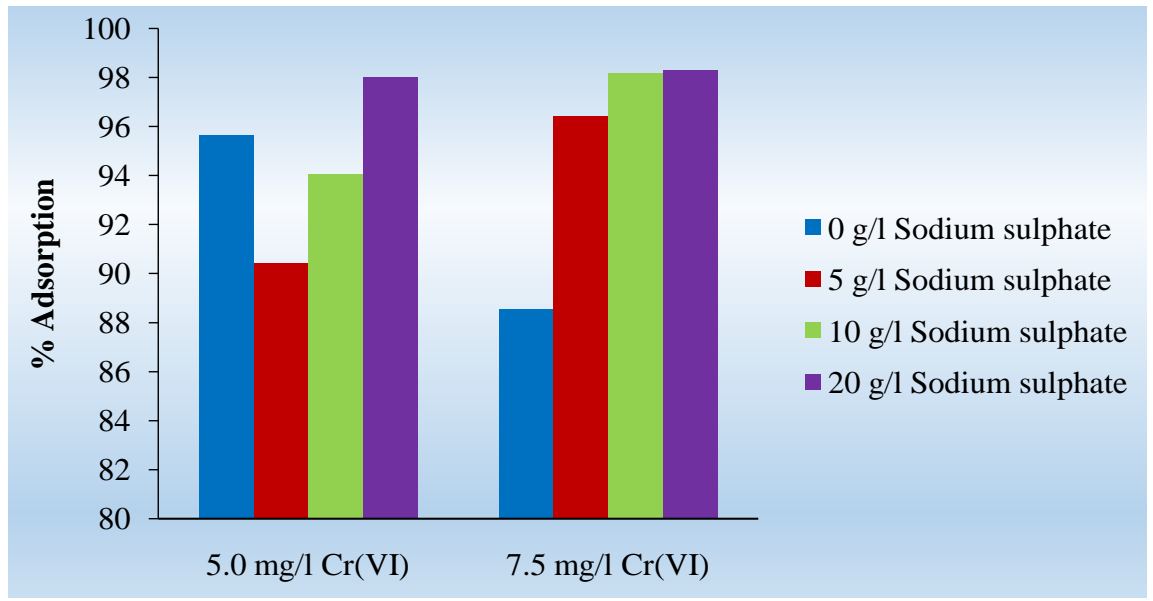

Figure 10. The effect of $\mathrm{SO}_{4}^{2-}$ ion on $\mathrm{Cr}(\mathrm{VI})$ adsorption by JSP. 
Table 2. The effect of other ions on the adsorption by JSP at 5.0 and $7.5 \mathrm{mg} \cdot \mathrm{l}^{-1} \mathrm{Cr}(\mathrm{VI})$.

\begin{tabular}{|c|c|c|c|c|c|}
\hline Salt & {$[\mathrm{Cr}(\mathrm{VI})](\mathrm{mg} / \mathrm{l})$} & [Salt] (g/l) & $C_{e}(\mathrm{mg} / \mathrm{l})$ & $Q_{e}(\mathrm{mg} / \mathrm{g})$ & $A_{e q}(\%)$ \\
\hline \multirow{8}{*}{$\mathrm{NaCl}$} & \multirow{4}{*}{5.0} & 0 & 0.2185 & 0.2391 & 95.63 \\
\hline & & 5 & $0.2819^{*}$ & 0.2359 & 94.36 \\
\hline & & 10 & $0.4087^{\star * *}$ & 0.2296 & 91.83 \\
\hline & & 20 & $0.5708^{* * * *}$ & 0.2215 & 88.58 \\
\hline & \multirow{4}{*}{7.5} & 0 & 0.8598 & 0.3320 & 88.54 \\
\hline & & 5 & $1.1276^{*}$ & 0.3186 & 84.97 \\
\hline & & 10 & $1.4376^{\star *}$ & 0.3031 & 80.83 \\
\hline & & 20 & $1.8745^{\star * * *}$ & 0.2813 & 75.01 \\
\hline \multirow{8}{*}{$\mathrm{Na}_{2} \mathrm{SO}_{4}$} & \multirow{4}{*}{5.0} & 0 & 0.2185 & 0.2391 & 95.63 \\
\hline & & 5 & $0.4972^{\star *}$ & 0.2251 & 90.42 \\
\hline & & 10 & $0.2960^{*}$ & 0.2352 & 94.08 \\
\hline & & 20 & 0.0987 & 0.2451 & 98.03 \\
\hline & \multirow{4}{*}{7.5} & 0 & 0.8598 & 0.3320 & 88.54 \\
\hline & & 5 & 0.2678 & 0.3616 & 96.43 \\
\hline & & 10 & 0.1382 & 0.3681 & 98.16 \\
\hline & & 20 & 0.1263 & 0.3687 & 98.32 \\
\hline \multirow{8}{*}{$\mathrm{KNO}_{3}$} & \multirow{4}{*}{5.0} & 0 & 0.2185 & 0.2391 & 95.63 \\
\hline & & 5 & $0.5567^{\star * *}$ & 0.2222 & 88.87 \\
\hline & & 10 & $0.7259^{* * * *}$ & 0.2137 & 85.48 \\
\hline & & 20 & $1.1783^{* * * *}$ & 0.1911 & 76.43 \\
\hline & \multirow{4}{*}{7.5} & 0 & 0.8598 & 0.332 & 88.54 \\
\hline & & 5 & $1.4235^{\star *}$ & 0.3038 & 81.02 \\
\hline & & 10 & $1.9168^{* * *}$ & 0.2792 & 74.44 \\
\hline & & 20 & $2.5652^{\star * * *}$ & 0.2467 & 65.80 \\
\hline
\end{tabular}

${ }^{*}(\mathrm{p} \leq 0.05),{ }^{* *}(\mathrm{p} \leq 0.005),{ }^{* * *}(\mathrm{p} \leq 0.0005)$ and ${ }^{* * *}(\mathrm{p} \leq 0.00005)$.

equilibrium parameter $R_{L}$, which is defined by the following relationship:

$$
R_{L}=\frac{1}{1+K_{a} C_{o}}
$$

The parameter $R_{L}$ indicates the shape of the isotherm accordingly; if $R_{L}>1$, adsorption is unfavourable; $R_{L}=1$, Linear adsorption; $R_{L}=0$, irreversible adsorption; therefore, $R_{L}$ has a shape of $0<R_{L}<1$ for the sorption process to be favourable [18].

Rearranging the equation, a linear equation is obtained

$$
\frac{C_{e}}{Q_{e}}=\frac{1}{K_{a} Q_{m}}+\frac{C_{e}}{Q_{m}}
$$

A linear plot of $C_{e} / Q_{e}$ vs. $C_{e}$, in Figure 11 was obtained and used to determine $Q_{m}$, and $K_{a}$.

Additionally, the empirical data was fitted to the Freundlich adsorption isotherm, which can be expressed as below: 


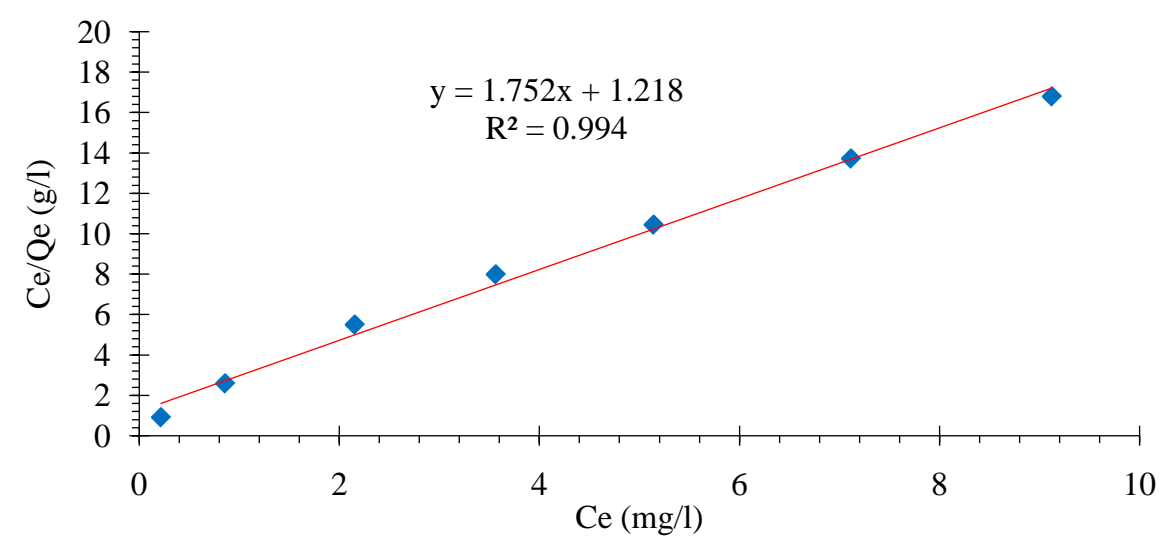

Figure 11. Langmuir isotherm for $\mathrm{Cr}(\mathrm{VI})$ adsorption by jackfruit seed powder.

$$
Q_{e}=K_{f} C_{e}^{1 / n}
$$

The Freundlich isotherm being empirical, it is used for non-ideal adsorption and when the surface is heterogeneous. This isotherm describes nonlinear adsorption where $K_{f}$ is the Freundlich constant, indicating the relative adsorption capacity related to the binding energy. The factor $n$, known as heterogeneity factor, represents the deviation from linearity of the adsorption. The linearised form of the Freundlich model is as shown below:

$$
\log Q_{e}=\log K_{f}+\frac{1}{n} \log C_{e}
$$

A linear plot of $\log Q_{e}$ vs. $\log C_{e}$ yielded Freundlich isotherm at $25^{\circ} \mathrm{C}$.

The experimental results were fitted into the Langmuir as per Figure 11 and Freundlich isothermsas per Figure 12 as shown above and the constants obtined from the obtained plots are presented in Table 3. According to the values of $R_{L}$ obtained from the Langmuir isotherm, which were found to be between 0.0336 and 0.1220 for the used initial concentration range, indicated that the adsorption of $\mathrm{Cr}(\mathrm{VI})$ by JSP was judged to be favourable.

\subsection{Comparison with Other Adsorbents}

Maximum adsorption capacity $\left(Q_{m}\right)$ of $\mathrm{Cr}(\mathrm{VI})$ using JSP was $0.57 \mathrm{mg} / \mathrm{g}$, which compared well with those reported in literature for other bioadsorbents (Table 4).

Activated rice husk carbon, activated alumina and modified oak sawdust exhibited higher $Q_{m}$ owing to the high initial carbon content, activation process as well as the pore development due to the basic morphology of the raw material [19].

\section{Conclusions}

JSP successfully demonstrated the ability to remove $\mathrm{Cr}(\mathrm{VI})$ from aqueous acidic solution and its $Q_{m}$ compared well with those of other bio adsorbents reported in literature. $\mathrm{Cr}(\mathrm{VI})$ removal percentage by JSP was dependent on $\mathrm{pH}$, temperature, contact time, adsorbent doses, and initial $\mathrm{Cr}(\mathrm{VI})$ concentration. Furthermore, it 


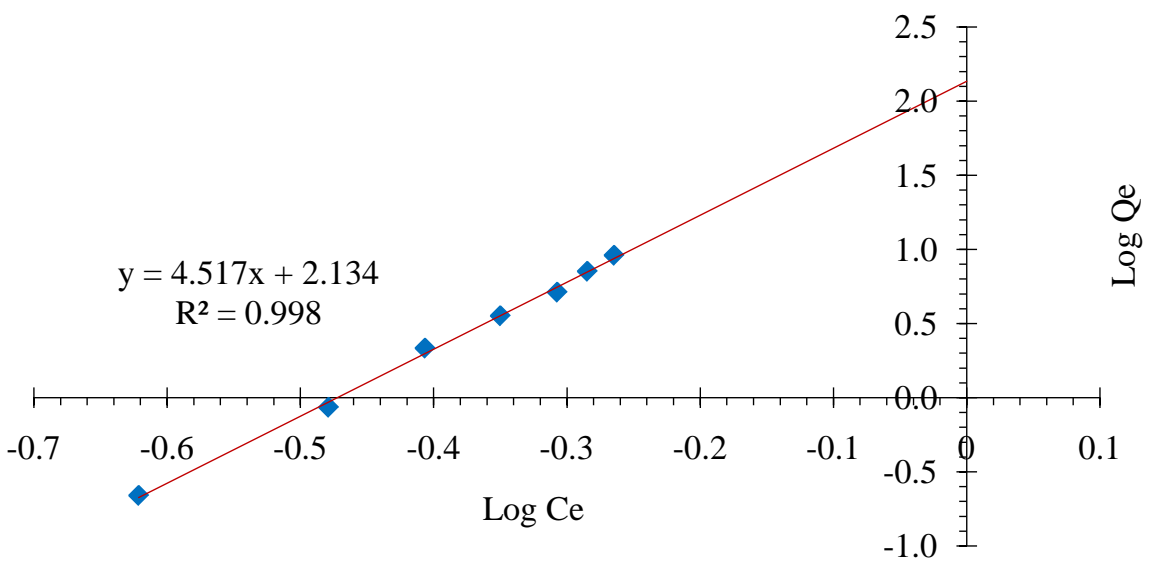

Figure 12. Freundlich isotherm for $\mathrm{Cr}(\mathrm{VI})$ adsorption by JSP.

Table 3. Estimated isotherm parameters for $\mathrm{Cr}(\mathrm{VI})$ adsorption JSP.

\begin{tabular}{ccc}
\hline Isotherm & $R^{2}$ & Estimated isotherm parameters \\
\hline Freundlich & 0.998 & $K_{f}=134.896, n=0.2213$ \\
& 0.994 & $Q_{m}=0.57 \mathrm{mg} / \mathrm{g}, K_{a}=1.44 \mathrm{~L} / \mathrm{mg}$ and \\
Langmuir & $R_{L}=0.0336-0.1220$ \\
\hline
\end{tabular}

Table 4. Comparison of adsorption capacities of $\mathrm{Cr}(\mathrm{VI})$ with other adsorbents.

\begin{tabular}{ccccc}
\hline Adsorbents & $Q_{m}(\mathrm{mg} / \mathrm{g})$ & $\mathrm{pH}$ & $C_{o}(\mathrm{mg} / \mathrm{l})$ & Reference \\
\hline Activated rice husk carbon & 0.8 & 2 & 10 & {$[20]$} \\
Activated alumina & 1.6 & 4 & 10 & {$[20]$} \\
Sawdust & 0.229 & 2 & 5 & {$[21]$} \\
Pine leaves & 0.277 & 2 & 5 & {$[21]$} \\
Raw rice bran & 0.07 & 2 & 5 & {$[22]$} \\
Modified oak sawdust & 1.7 & 3 & - & {$[23]$} \\
CETYL-amended zeolite & 0.65 & - & - & {$[24]$} \\
EHDDMA-amended zeolite & 0.42 & - & - & Present study \\
Jackfruit seed Powder (JSP) & 0.57 & 2 & 5 & \\
\hline
\end{tabular}

was found out that $\mathrm{Cr}(\mathrm{VI})$ adsorption strongly depended on initial $\mathrm{pH}$ of the solution. Thus, the removal of $\mathrm{Cr}(\mathrm{VI})$ is highly applicable at very low $\mathrm{pH}$ values owing to the need for protonation of the surface active sites of JSP. Thermodynamic investigation showed that the process is spontaneous even at room temperature. The affinity of JSP for the $\mathrm{Cr}(\mathrm{VI})$ increases with temperature as well as the process being majorly chemisorption, as portrayed by positive standard entropy changes. The positive value of enthalpy change indicates that the reaction is endothermic.

Both Freundlich and Langmuir adsorption models well described the equilibrium data of $\mathrm{Cr}(\mathrm{VI})$ adsorption by JSP as the data best fitted both with high regression coefficients. According to Langmuir model, the monolayer adsorption capacity $\left(Q_{m}\right)$ was found to be $0.57 \mathrm{mg}$ of $\mathrm{Cr}(\mathrm{VI})$ per gram of JSP. The obtained 
$Q_{m}$ implies that JSP is a better adsorbent as compared to saw dust, pine leaves, raw rice bran among others. Therefore, JSP is a potential adsorbent for chromium(VI) contaminated water. Finally, it was observed that the adsorption efficiency of $\mathrm{Cr}(\mathrm{VI})$ by JSP was highly influenced by interfering ionic species present in the matrix. Therefore, it is important to have an idea of the ionic species present in the effluent before the use of JSP to remediate it or the effectiveness of JSP to remove $\mathrm{Cr}(\mathrm{VI})$ from aqueous environments will greatly depend on the chemical components present. Similarly, because percentage adsorption decreases with increasing $\mathrm{Cr}(\mathrm{VI})$ concentration, it would be better to increase the amount of the JSP used as well as contact time in the case of highly polluted water systems.

\section{References}

[1] United Nations Industrial Development Organization (UNIDO) (2002) The Leather Sector in Uganda.

[2] Muwanga, A. and Barifaijo, E. (2006) Impact of Industrial Activities on Heavy Metal Loading and Their Physico-Chemical Effects on Wetlands of Lake Victoria Basin (Uganda). African Journal of Science and Technology, 7, 51-63.

[3] Oguttu, H.W., Bugenyi, F.W., Leuenberger, H., Markus, W. and Bachofen, R. (2008) Pollution Menacing Lake Victoria: Quantification of Point Sources around Jinja Town, Uganda. Water $S A$, 34, 89-98.

[4] Hema Krishna, R. and Swamy, A.V.V.S. (2012) Investigation on the Adsorption of Hexavalent Chromium from the Aqueous Solutions Using Powder of Papaya Seeds as a Sorbent. International Journal of Environmental Sciences and Research, 2, 119125.

[5] Ghebremichael, K., Gebremedhin, N. and Amy, G. (2010) Performance of Moringa oliefera as a Biosorbent for Chromium Removal. Water Science and Technology, 62, 1106-1111. https://doi.org/10.2166/wst.2010.413

[6] Nameni, M., Alavi Moghadam, R. and Arami, M. (2008) Adsorption of Hexavalent Chromium from Aqueous Solutions by Wheat Bran. International Journal of Environmental Science \& Technology, 5, 161-168. https://doi.org/10.1007/BF03326009

[7] Baral, S.S., Das, S.N. and Rath, P. (2006) Hexavalent Chromium Removal from Aqueous by Adsorption on Treated Sawdust. Biochemical Engineering Journal, 13, 216-222. https://doi.org/10.1016/j.bej.2006.08.003

[8] APHA (2005) SM 3550. Standard Methods for examination of Water and Waste Water. Analytical Public Health Association, Washington DC.

[9] APHA (2005) SM 3111B. Standard Methods for Examination of Water and Waste Water. Analytical Public Health Association, Centennial Edition, Washington DC.

[10] Krika, F., Azzouz, N. and Ncibi, M.C. (2012) Removal of Hexavalent Chromium from Aqueous Media using Mediterranean Posidonia oceanica Biomass: Adsorption Studies and Salt Competition Investigation. International Journal of Environmental Research, 6, 719-732.

[11] Arivoli, S., Nandhakumar, V., Saravanan, S. and Nagarajan, S. (2009) Adsorption Dynamics of Copper Ion by Low Cost Activated Carbon. The Arabian Journal for Science and Engineering, 34, 1-12.

[12] Maryam, S. and Ahmadpour, A. (2011) Biosorption of Hexavalent Chromium Ions from Aqueous Solutions using Almond Green Hull as a Low-Cost Biosorbent. Eu- 
ropean Journal of Scientific Research, 58, 392-400.

[13] Mina, G., Hassan, H. and Maryam, M. (2011) Hexavalent Chromium Removal from Aqueous Solution via Adsorption on Granular Activated Carbon: Adsorption, Desorption, Modeling and Simulation Studies. ARPN Journal of Engineering and Applied Sciences, 6, 10-18.

[14] Lakshmipathiraj, P., Umamaheswari, S., Bhaskar Raju, G., Prabhakar, S., Caroling, G., Kato, S. and Kojima, T. (2011) Studies on Adsorption of Cr(VI) onto Strychnos potatorum Seed from Aqueous Solution. Environmental Progress \& Sustainable Energy, 32, 35-41. https://doi.org/10.1002/ep.10595

[15] Pandey, P.K., Sharma, S.K. and Sambi, S.S. (2010) Kinetics and Equilibrium Study of Chromium Adsorption on zeoliteNaX. International Journal of Environmental Science \& Technology, 7, 395-404. https://doi.org/10.1007/BF03326149

[16] Vagars, C., Brandao, P.F.B., Agenda, J. and Castillo, E. (2012) Bioadsorption Using Compost: An Alternative for Removal of Chromium(VI) from Aqueous Solutions. BioResource, 7, 2711-2727.

[17] Hawley, E.L., Deeb, R.A. and Kava, M.C. (2004) Treatment Technology for Chromium(VI). In: Editors, Chromium(VI) Handbook, Publisher, Location, 273-308.

[18] Khaldounl-Sou'od (2012) Kinetics of the Adsorption of Hexavalent Chromium from Aqueous Solutions on Low Cost Material. African Journal of Pure and Applied Chemistry, 6, 190-197.

[19] Garg, V.K., Gupta, R., Kumar, R. and Gupta, R.K. (2004) Adsorption of Chromium from Aqueous Solution on Treated Sawdust. Bioresource Technology, 92, 79-81. https://doi.org/10.1016/j.biortech.2003.07.004

[20] Bishnoi, N.R., Bajaj, M., Sharma, N. and Gupta, A. (2004) Adsorption of Cr(VI) on Activated Rice Husk Carbon and Activated Alumina. Bioresource Technology, 91, 305-307. https://doi.org/10.1016/S0960-8524(03)00204-9

[21] Morshedzadeh, K., Soheilizadeh, H.R., Zangoie, S. and Aliabadi, M. (2007) Removal of Chromium from Aqueous Solutions by Lignocellulosic Solid Wastes. International 1 st Environment Conference, Location, Date, Page.

[22] Oliveira, E.A., Montanher, S.F., Andrade, A.D., Nobrega, J.A. and Rollemberg, M.C. (2005) Equilibrium Studies for the Sorption of Chromium and Nickel from Aqueous Solutions Using Raw Rice Bran. Process Biochemistry, 40, 3485-3490. https://doi.org/10.1016/j.procbio.2005.02.026

[23] Argun, M.E., Dursun, S., Ozdemir, C. and Karatas, M. (2006) Heavy Metal Adsorption by Modified Oak Sawdust: Thermodynamics and Kinetics. Journal of Hazardous Materials, 141, 77-85. https://doi.org/10.1016/j.jhazmat.2006.06.095

[24] Santiago, I., Worland, V., Cazares, E. and Cadena, F. (1992) Adsorption of Hexavalent Chromium onto Tailored Zeolites. 47 th Purdue Industrial Waste Conference Proceedings, Inc., Chelsea, MI. 
Submit or recommend next manuscript to SCIRP and we will provide best service for you:

Accepting pre-submission inquiries through Email, Facebook, LinkedIn, Twitter, etc. A wide selection of journals (inclusive of 9 subjects, more than 200 journals)

Providing 24-hour high-quality service

User-friendly online submission system

Fair and swift peer-review system

Efficient typesetting and proofreading procedure

Display of the result of downloads and visits, as well as the number of cited articles Maximum dissemination of your research work

Submit your manuscript at: http://papersubmission.scirp.org/

Or contact jwarp@scirp.org 